Uşak Üniversitesi Sosyal Bilimler Dergisi

$2015,8 / 2$

\title{
İlkokullarda Görev Yapan Okul Müdürlerinin Genel Öz Yeterlik ile Örgütsel Bağlılık Algıları Arasındaki İlişkinin İncelenmesi
}

\author{
Ahmet AYIK \\ Mücella SAVAŞ $S^{* *}$ \\ Engin YÜCEL ${ }^{* * *}$
}

Öz

Bu araştırmada, ilkokullarda görev yapan okul müdürlerinin genel öz yeterlik inançları ile örgütsel bağlılıkları arasındaki ilişkinin belirlenmesi amaçlanmıştır. Araştırmanın örneklemini, basit rastlantısal örnekleme tekniği ile seçilen Erzurum il merkezinde bulunan ilkokullarda görevli 101 okul müdürü oluşturmaktadır. Verilerin toplanmasında, Genel Öz yeterlik Ölçeği ve Üç Boyutlu Örgütsel Bağlılık Ölçeği kullanılmıştır. Betimsel bir çalışma olan bu araştırmada verilerin çözümlenmesinde standart sapma, ortalama, Pearson Momentler Çarpım korelasyonu ve çoklu doğrusal regresyon analizinden faydalanılmıştır. Araştırma sonuçları, okul müdürlerinin genel öz yeterlik ile örgütsel bağlllıkları arasında pozitif yönde anlamlı ilişki olduğunu göstermiştir. Regresyon analizi sonuçlarına göre, genel öz yeterliğin yetenek ve güven boyutu, örgütsel bağlllığın normatif bağlllık boyutunu pozitif yönde ve anlamlı düzeyde yordamıştır. Araştırma sonuçları, okul müdürlerinin genel öz yeterliklerinin örgütsel bağlllıkları üzerine etkisi çerçevesinde tartışılmıştır.

Anahtar Kelimeler: Örgütsel Bağlllık, Öz Yeterlik, Genel Öz Yeterlik, Okul Müdürleri.

\section{A Study of Relationship between General Self-Efficacy of Elementary} School Principals and Perceptions of Their Organizational Commitment

\section{Abstract}

In this study, it is aimed to determine the relationship between the general self-efficacy beliefs of elementary school principals and their

\footnotetext{
* Yrd. Doç. Dr., Atatürk Üniversitesi Kazım Karabekir Eğitim Fakültesi Eğitim Yönetimi Teftişi Planlaması ve Ekonomisi ABD.

** Arş. Gör. Atatürk Üniversitesi Kazım Karabekir Eğitim Fakültesi Eğitim Yönetimi Teftişi Planlaması ve Ekonomisi ABD.

${ }^{* * *}$ Maarif Müfettişi, Milli Eğitim Bakanlığı.
} 
organizational commitment. The sample of this study consists of 101 school principals working at primary schools in Erzurum by the technique of simple random sampling. General Self-Efficacy Scale and Three Dimensional Organizational Commitment Scale were used for data collection. In analysis of the data, in this research which is a descriptive study, standard deviation, mean, Pearson 's product-moment correlation and multiple linear regression analysis were utilized. Research results showed that there is a significant and positive relationship between general self-efficacy of school principals and their organizational commitment. According to results of regression analysis, the ability and confidence of which is dimensions of general self-efficacy of school principals predicted significantly and positively their perceptions of normative commitment. At the results of the study, the impact of general self-efficacy of school principals on their organizational commitment was discussed.

Key Words: Organizational Commitment, Self-Efficacy, General Self-Efficacy, School Principals.

\section{Giriş}

Yoğun rekabetin ve hızlı değişimlerin olduğu günümüzde örgütlere bakıldığında kendilerini sürekli yenileyen ve geliştiren yeni arayışlar içinde oldukları dikkat çekmektedir. Kurumlar örgütsel etkililiği ve verimliliği sağlamanın çeşitli yollarını aramaktadır. Bu etkililiği ve verimliliği sağlamak, sürekli gelişimi artırmak için örgütte bulunan tüm işgörenlerin yüksek bir çaba sarf etmesi, çalışanların örgüte olumlu duygular beslemesi ve işgörenlerin örgütte tutulması gerekmektedir. Bu durum ise örgütsel bağlılık kavramını ortaya çıkarmıştır. Bağlılık duyan işgörenler, örgütün amaç ve değerlerine güçlü bir biçimde inanır, emir ve beklentilere gönüllüce uyarlar. Bu üyeler ayrıca, amaçların istenen şekilde gerçekleşmesi için asgari beklentilerin çok üstünde çaba ortaya koyar ve örgütte kalmada kararlılık gösterirler (Karcıŏlu ve Çelik, 2012). Bu bağlamda örgütsel başarıyı sağlamak için işgörenlerin özellikle de okul müdürlerinin örgütsel bağlılığının güçlü olması gerekmektedir.

Eğitim sisteminin temelini okullar oluşturmaktadır. Okuldaki eğitim ve öğretim faaliyetlerinin genel amacl; bir ülkenin geleceği olan çocukların bilgi, yeterlik ve davranış olarak sağlıklı ve verimli şekilde yetişmelerini sağlamaktır (Karakuş ve Töremen, 2006). Okullar, bireyleri belli bir amaca göre yetiştirmeyi hedefler ve bireyin topluma ayak uydurmasına yardım ederek ilgi ve yetenekleri doğrultusunda yetiştirir. $\mathrm{Bu}$ bağlamda okul müdürünün belli bilgi, beceriye ve okul yönetimi 
konusunda yeterliliğe sahip olması gerekmektedir. Ancak okul müdürlerinin sadece belli yeterliklere sahip olması gerekmez ayrıca buna inanması da gerekir. İnsanlar etkili biçimde bir sorunu çözebileceklerine inanırlarsa, aldıkları kararları gerçekleştirmek için daha istekli hale gelirler (Schwarzer vd., 1997). Okul müdürlerinin yeteneklerine inanması okulun hedeflerine bağlanmasını ve bu hedefleri gerçekleştirmekte daha fazla çaba harcamalarını sağlayabilir. Literatürde, yönetici yeterliliğini inceleyen birçok araştırma yapılmıştır. Elde edilen araştırmalarda yönetici yeterliliklerinin; iletişim (Topluer, 2008), çatışma yönetimi (Elma, 1998), insan kaynaklarını yönetme (Çalık ve Şehitoğlu, 2006; Türkmen, 2008), liderlik (Arslan ve Beytekin, 2004; Babaoğlan ve Litchka, 2010), uzmanlık (Çetin ve Adıgüzel, 2006), teknoloji (Banoğlu, 2011; Bülbül ve Çuhadar, 2012; Can, 2003; Y1lmaz, 2008), değişim yönetimi (Ak, 2006; Gökçe, 2008), parasal kaynakları yönetme (Menteşe vd., 2012) ve bilgi yönetimi (Çınar, 2004; Memişoğlu ve Özsarıkamış, 2009) ile ilişkili olduğu bulgulamıştır. Genel olarak yönetici yeterlikleri de (Ağaoğlu vd., 2012; Kombıçak, 2008; Leithwood ve Jantzi, 2008; Okutan ve Kahveci, 2012; Peker ve Selçuk, 2011; Şahin, 2000; Karakuş ve Töremen, 2006; Tschannen-Moran ve Gareis, 2004; Tschannen-Moran ve Gareis, 2005) çeşitli araştırmacılar tarafından incelenmiştir.

\subsection{Okul Yöneticilerinin Yeterlikleri}

Okulun amaçlarını gerçekleştirecek, yapısını yaşatacak ve havasını koruyacak iç öğelerin lideri okul müdürü olmalıdır (Bursalıoğlu, 2012: 40). Çağdaş okul yöneticisi; kapsamlı insan bilgisine ulaşmış, etkili iletişim becerisine sahip, liderlik özellikleri baskın, anadilini doğru ve güzel kullanabilen, felsefe, matematik, uygarlık tarihi eğitimi görmüş, yabancı dil bilen, iletişim teknolojisine hakim, bilgiyi yöneten, beden ve ruh yönünden sağlıklı, eğitime inanmış yöneticidir (Açıalın, 1994). Okul yöneticisi, bir eğitim lideri olarak okulda anlamların yönetimini sağlayabilecek bazı yeterliklere sahip olmalıdır. Böylece yönetici, okulun anlamını daha iyi anlayacak, bir takım sembolleri, okulların amaçlarının gerçekleşmesinde etkili bir biçimde kullanabilecektir (Şişman, 2012: 11).

Yeterlik, bireyin görevlerini yapabilmesi ve sorumluluklarını yerine getirmesi için ihtiyaç duyduğu yetenek ve bilgileri (Okutan ve Kahveci, 2012) ve en genel anlamıyla örgütsel etkililiği sağlamada yöneticilerden beklenenleri ifade etmektedir (Ağaoğlu ve diğerleri, 2012). Literatür incelendiğinde yöneticilerin sahip olması gereken yeterliklerin; teknik, insancıl ve kavramsal yeterlikler olarak üç grupta sinıflandırıldığı görülmektedir; 
1. Teknik yeterlikler: Kişinin çalışma alanına göre, somut olarak yapabileceği, uzmanlık bilgisine bağlı bilgi ve beceridir. Bunlar; a) Yöneticinin, okul maliyesinin kuram ve ilkelerinde uzman olması, b) Okulun iç maliyesi ve işletme yönetimi, c) Okul binalarının bakımı ve hizmete hazır tutulması, d) Okur binalarının planlanmasıdır (Aydın, 2010: 203-204).

2. Insancıl yeterlikler: Etkili çalışma ve ortak çaba oluşturabilme, başkaları hakkındaki varsayım, inanç ve tutumları, bunların kullanılış yöntem ve sınırlarını görebilme, bireysel farklılıkları gözetme gibi insan ilişkilerine yönelik özellikler olarak görülebilir (Başar, 2000: 105). Birey ve grupları anlama ve güdüleme yeterlikleri olarak da kabul edilebilir.

3. Kavramsal yeterlikler: Okulu bulunduğu toplum, eğitim sistemi ve evrensel ölçüler içerisinde görebilme, okulun sosyal, kültürel ve ekonomik çevresini sürekli takip ederek, meydana gelen değişmeler ve gelişmelere kolaylıkla uyum sağlayabilecek nitelikte bir öğrenen okulu oluşturabilme (Simard ve Rice, 2006 Aktaran: Karakuş ve Töremen, 2006) becerilerini içermektedir.

\section{2. Öz Yeterlik}

Öz yeterlik Bandura'ya (1994) göre bireyin, yaşamını etkileyen olaylar üzerinde kendisinden beklenen performansı sergilemesi için kendi yetenekleri hakkındaki inançları olarak tanımlanırken, Leithwood ve Jantzi'e (2008) göre ise öz yeterlik duygusu, bir görevi yerine getirmek ya da bir hedefi başarmak için kendi yeteneğine veya grup halinde çalışırken iş arkadaşlarının yeteneğine olan inancı olarak ifade edilmiştir. Öz yeterlik yetenekli olmaya değil, kişinin kendi kaynaklarına güvenmesine karşılık gelir (Yıldırım ve İlhan, 2010). Öz yeterlik inancı bireyin hoşuna gitmeyen durumlarla karşılaştı̆̆ında ortaya koyduğu mücadele gücüne ve ne kadar süre bu sorunlarla yüz yüze kalabildiğine işaret etmektedir (Uysal ve Kösemen, 2013). Öz yeterlik kavramı, bir eylemin planlanması, gerekli becerilerin farkında olunması ve örgütlenmesi, zorluklarla birlikte elde edilecek kazançların gözden geçirilmesi sonucunda oluşan güdülenme düzeyi gibi öğeleri içerir (Yıldırım ve İlhan, 2010).

Öz yeterlik inancı insanların nasıl hissedip, düşündüğünü ve kendilerini nasıl motive edip ve davranacağını belirler (Bandura, 1994). Öz yeterlik, diğer faktörlerin yanı sıra, insanların hangi zorlukların üstesinden geleceklerine karar vermelerini ve hedeflerinin ne kadar yüksek olmasını etkiler. Belirli bir alanda yüksek öz yeterliliğe sahip kişiler daha zorlu ve iddialı hedefler seçer. Yüksek öz yeterlik sadece kişinin hedef belirlemesini sağlamaz, ayrıca hedefini sürdürmede daha ısrarcı olmasını da sağlar. Bu 
nedenle, öz yeterliği yüksek bireyler daha gerçekçi amaçlara sahiptir (Luszczynska, Scholz ve Schwarzer, 2005). Öz yeterlik kuramcilarına göre, düşük öz yeterlik motivasyonel problemlere neden olur. Öğrenciler belirli işlerde başarısız olacağına inanırsa bu işlere yüzeysel olarak çalışırlar, çabucak terk ederler, direnir ve kaçınırlar. Düşük öz yeterlik ne yazık ki akademik başarıya engel olur, uzun vadede öğrenilmiş çaresizlik ve kendini gerçekleştiren kehanet yaratır (Hsieh, Sullivan ve Guerra, 2007).

Öz yeterlik inançları bilişsel, güdüsel, duyuşsal ve karar verme süreçleri ile insan işleyişini düzenler (Benight ve Bandura, 2004). Öz yeterliliğin insan davranışlarını bu derece etkilemesi önce Bandura (1993, 1994), daha sonra da birçok araştırmacı tarafından incelenmiştir (Azar, 2010; Fan ve Williams, 2010; Hsieh vd., 2007; Gençtürk ve Memiş, 2010; Kahyaoğlu ve Yangın, 2007; Luszczynska vd., 2005; McCollum, Kajs ve Minter, 2005; Margolıs ve Mcabe, 2003; Margolıs ve Mcabe, 2006; Pajares, 2002; Somech ve Drach-Zahavy, 2000; Schunk, 1991; Ünal- Keskin ve Orgun, 2006; Üstüner, Demirtaş, Cömert ve Özer, 2009; Vuong, Brown-Welty, ve Tracz, 2010; Yost, 2010; Zimmerman, 2000). Okul yöneticilerinin genel öz yeterliklerini inceleyen sınırlı sayıda çalışmaya ulaşılmıştır (Okutan ve Kahveci, 2012).

\section{3. Örgütsel Bağglllk}

Örgütsel bağll1ık, işgörenlerin çalıştığı örgüte karşı hissettiği bağın gücünü ve çalışanların örgüte yönelik hisleri ve tutumlarını ifade etmektedir (Güney, 2011: 276-277). Örgütsel bağlllık; çalışanların kendi istekleri ya da çıarları doğrultusunda örgütte kalmak istemeleri, örgütün değerlerini kendi değerleri ile özdeşleştirmeleri, örgütün başarıya ulaşması için çaba harcamaya istekli olmalarıdır (Somuncu, 2008).

Bir örgütteki işgörenlerin örgüte olan bağlll1klarından söz edebilmek için; işgörenlerin o örgütün bir üyesi olabilme amacına yönelik olarak güçlü bir istek duyması, kurumun yararını gözeterek yüksek düzeyde çaba sarf etmek istemesi, örgüte temel oluşturan değerlerini ve hedeflerini benimseyip kabullenmesi gerektiği vurgulanmaktadır (Erbaş, 2008). Örgütsel bağll1ık kavramı örgütün başarılı olabilmesi için işgörenin gösterdiği ilgiyi, örgüte karşı sadakati ve örgütsel değerlere duyulan inancı yansıtmaktadır (Kaya, 2008). Bağlllık duyan işgörenler, örgütün amaç ve değerlerine güçlü bir biçimde inanır, emir ve beklentilere gönüllüce uyarlar. $\mathrm{Bu}$ üyeler ayrıca, amaçların istenen şekilde gerçekleşmesi için asgari beklentilerin çok üstünde çaba ortaya koyar ve örgütte kalmada kararlllık gösterirler (Karcıoğlu ve Çelik, 2012). 
Örgütsel bağlılığın bireysel ve örgütsel açıdan bazı olumlu sonuçları bulunmaktadır (Sezgin, 2010). Örgütsel bağlllıkta birey kendisini örgütle bütünleştirmekte ve örgütün çıkarlarını kendi çıkarlarının üstünde tutmaktadır (Başyiğit, 2006). Örgüte bağlllığı güçlü olan kimseler işlerinden ayrılmak istemeyeceklerdir. İşten ayrılmanın yanı sıra, işe devamsızlık azalmakta ve çalışan işine daha çok sahip çıarak, iyi işler yapmak için işletmeye katkıda bulunur (Ekinci, 2006). Bağlllık her zaman kişinin başarısının ardındaki itici güç olarak görülmektedir. Kendini işine adamış bir kişi engellerle karşılaşsa bile işini tamamlayıncaya kadar devam etmek isteyecektir. Onun bağlllığı bu zorlukların üstesinden gelmesi için ona yardım edecektir (Tolentino, 2013).

İşgörenin, örgüte bağlllığı duygusal, devam ve normatif olarak üç şekilde boyutlandırılmıştır. Duygusal bağhllık, işgörenin örgütsel amaçları ve örgütün değerlerini benimsemesinden kaynaklanmaktadır (Yavuz ve Tokmak, 2009). Duygusal bağl1lı̆̆ı güçlü olan çalışanlar örgütlerinin değerlerini, hedeflerini ve amaçlarını benimser; örgütün bir parçası olarak kalmak isterler (Gürbüz, 2006). Devam bağhllı̆̆ı, işgörenlerin örgütten sağladığ 1 değerler üzerine temellenir. Bağlılığın bu türü ile işgörenler bazı değerleri (gelir, fayda, kıdem) kaybetmekten kaçındığı için örgütte kalırlar (Tolentino, 2013). Normatif bağ lılık, çalışanın örgüte olan sadakatinde veya gönüllügünde kendisini zorunlu hissetmesidir. $\mathrm{Bu}$ his örgüt üyelerinin baskısı ve örgüt kültürünün etkisi sonucu oluşmaktadır (Demirel, 2008).

$\mathrm{Bu}$ bağlamda örgütsel bağlılığın örgütsel yaşamın başarısı ve sürekliliği için gerekli bir özellik olduğu görülmektedir. Literatür incelendiğinde örgütsel bağlllığın, örgütsel destek ve adaletle insan kaynakları uygulamalarıyla (Meyer ve Smith 2000), örgütsel vatandaşlık davranışı (Feather ve Rauter, 2004; Gürbüz; 2006), mesleki stres ve iş tatmini (Aghdasi, Kiamanesh, ve Ebrahim, 2011), örgütsel destek (Panaccio ve Vandenberghe, 2009), örgütsel iklim (Cullen, Parboteeah, ve Victor, 2003; Korkmaz, 2011; Schwepker, 2001), kurumsal etik değerler (Valentine, Godkin, ve Lucero, 2002), örgütsel öğrenme, iş tatmini ve iş performansı (Rose ve diğerleri, 2009), örgüt kültürü (Erdem, 2007; Kaya; 2008; Silverthorne, 2004), örgütsel iletişim (Ada, Alver ve Atlı, 2008; Başyiğit, 2006; Boyac1, 2010; Carriere ve Bourque, 2009; Ekinci, 2006), tükenmişlik düzeyleri (Çetin vd., 2011; Tulunay, 2010) ile ilişkisi bulunmuştur. Bu değişkenlere ek olarak örgütsel bağlllıkla liderlik ilişkisini araştıran çalışmalar da vardır (Avolio vd., 2004; Buluç, 2009; Clinebell vd., 2013; Hemedoğlu ve Evliyaoğlu; 2012; Hulpia, Devos ve Keer, 2011; Kul ve Güçlü, 2010; Jackson vd., 2013; Joo vd., 2010; Yavuz ve Tokmak, 2009). Eğitim örgütü olan okulda örgütsel bağlılık, eğitimin amaçlarını en iyi şekilde 
gerçekleştirebilmesi için işgörenlerin tümünün sergilemesi gereken bir davranıştır.

Akkoyunlu, Orhan ve Umay'a (2005) göre öz yeterlik, bireylerin gelecekleri için bir amaç belirlemelerini, bu amaçlara ulaşmak için gösterecekleri çabayı, amaçlarına ulaşmak için karşılaşabilecekleri zorluklara ne kadar dayanabileceklerini ve başarısızlık yaşarlarsa, bu başarısızlık karşısında ne tepki vereceklerini etkilemektedir. Okul müdürlerinin karşılaştıkları sorunları çözebileceklerine olan inançları, yönettikleri okulda doğru eylemlerde bulunmalarına katkı sağlayacak ve bu eylemleri gerçekleştirmede kendilerini sorumlu hissedeceklerdir. Örgütsel bağlllık düzeyi yüksek olan işgörenler, kurumların başarılı olabilmesi için elinden geleni yapacak ve kendilerinden beklenenin ötesinde çaba sarf edeceklerdir (Güney, 2011: 291). Son yıllarda öz yeterlik konusunda çok sayıda bilimsel araştırma yapılmıştır (Bandura, 1994; Benight ve Bandura, 2004; Uysal ve Kösemen, 2013). Öğretmen öz-yeterliği çokça tartışılmış bir konu olmasına rağmen okul müdürlerinin öz-yeterliği konusu ihmal edilmiş bir alan olarak karşımıza çıkmaktadır (Akın, 2014; Black, 2003; Okutan ve Kahveci, 2012). Öz yeterlik algılarının da bireylerin davranışlarını ve performanslarını etkilediği bilinmektedir (Bandura, 1994). Bu nedenle okul müdürlerinin sahip oldukları genel öz yeterlik düzeylerinin eğitim öğretim sürecinin etkinliği açısından önemli olduğu ve okul müdürlerinin genel öz yeterlikleri ile örgütsel bağlılıkları arasında ilişki olduğu düşünülmektedir. $\mathrm{Bu}$ araştırmada ilkokullarda görev yapan okul müdürlerinin genel öz yeterlik ve örgütsel bağlılık algıları arasındaki ilişki incelenmiştir. Bu amaç çerçevesinde aşağıdaki sorulara cevap aranmıştır:

1. İlkokul müdürlerinin genel öz yeterlik ve örgütsel bağl1lığa ilişkin algıları ne düzeydedir?

2. İlkokul müdürlerinin genel öz yeterlik ve örgütsel bağllllğa ilişkin algıları arasında anlamlı ilişkiler var mıdır?

3. İlkokul müdürlerinin genel öz yeterliklerine ilişkin algıları örgütsel bağlılıklarını anlamlı düzeyde yordamakta mıdır?

\section{Yöntem}

Araştırmanın modelini tarama modellerinden ilişkisel tarama modeli oluşturmaktadır. İlişkisel tarama modelleri, değişkenler arasındaki ilişkileri saptamak (Sönmez ve Alacapınar, 2011) veya iki ve daha çok sayıdaki değişken arasında birlikte değişimin varlı̆̆ını ve/veya derecesini belirlemeyi amaçlayan araştırma modelleridir. İlişkisel tarama modeli gerçek bir neden-sonuç ilişkisi vermemekle birlikte bir değişkendeki 
durumun bilinmesi halinde ötekinin kestirilmesine olanak sağlamaktadır (Karasar, 2006).

\section{1. Çalışma Grubu}

Araştırmanın evrenini, 2013- 2014 eğitim öğretim yılında Erzurum il merkezindeki Milli Eğitim Bakanlığına bağlı 174 ilkokulda görev yapmakta olan okul müdürleri oluşturmaktadır. Çalışma grubu basit rastlantısal örneklem yöntemi ile belirlenen 101 ilkokulda görev yapan okul müdürleri oluşmaktadır. Bu örnekleme yönteminde evrendeki tüm birimler, örneğe seçilmek için eşit ve bağımsız bir şansa sahiptir. Diğer bir değişle tüm bireylerin seçilme olasılığ 1 aynıdır ve bir bireyin seçimi diğer bireylerin seçimini etkilememektedir (Büyüköztürk vd., 2012: 85). Katılımcıların 2'si (\%2) kadın, 99'u (\%98) erkektir. Araştırmaya katılan ilkokul müdürlerinin mesleki kıdeme göre dağılımı incelendiğinde, 11'i (\%10.9) 1-5 yıl, 17'si (\%16.8) 6-10 yıl, 38'i (\%37.6) 11-15 yıl, 26's1 (\%25.7) 16-20 y1l, 9'unun (\%8.9) 21 yıl ve üzeri mesleki kıdeme sahip olduğu görülmektedir.

\subsection{Veri Toplama Araçları}

Bu araştırmada veriler, Genel Öz Yeterlik Ölçeği, Örgütsel Bağlllık Ölçeği ve kişisel bilgi toplama formu ile toplanmıştır.

Genel Öz yeterlik Ölçeği: Genel Öz yeterlik Ölçeği, okul müdürlerinin genel öz yeterliliğe ilişkin algılarını belirlemek amacıyla ilk olarak 1979 yılında, Jerusalem ve Schwarzer tarafından geliştirilmiştir. On maddeden oluşan Ölçek Aypay (2010) tarafından Türkçe'ye uyarlanmıştır. Dörtlü likert tipi (tamamen yanlış=1 - tamamen doğru=4) ölçek formundaki ölçeğin faktör analizi sonuçları özdeğeri 1'in üstünde olan (2.64 ve 2.06) iki faktörlü bir yapı göstermiş ve bu faktörler toplamda varyansın \% 47'sini açılamıştır. Ölçek bileşenleri için Cronbach Alfa iç tutarlılık katsayıları .79 ve .63'tür. Toplamda hesaplanan Cronbach Alfa katsayısı .83'tür. Araştırmacılar tarafından yapılan güvenilirlik analizinde ölçeğin bütünü için Cronbach Alpha katsayısı .90, boyutlara ilişkin Cronbach Alpha güvenirlik katsayıları çaba ve direnç boyutu için .87, yetenek ve güven boyutu için .66, bulunmuştur.

Örgütsel Bă̆lllık Ölçeği: Araştırmada veri toplama aracı olarak Allen ve Meyer (1990) tarafından geliştirilen, Yıldırım (2002) tarafından Türkçeye uyarlanan "Üç Boyutlu Örgütsel Bağlllık Ölçeği” ve kullanılmıştır.

Örgütsel Bağlllık Ölçeği, beşli likert tipi derecelemeye sahip 18 maddeden ve duygusal bağlılık, devamlılık bağlllığ olmak üzere üç boyuttan oluşmaktadır. Ölçekte maddelerine ilişkin dereceleme seçenekleri Hiç Katılmıyorum (1), Biraz Katılıyorum (2), Orta 
Derecede Katıllyorum (3), Çok Katıllyorum (4), Tam Katılıyorum (5) biçiminde ifade edilmiştir. Ölçeğin Türkçe formunun alt boyutlarına ilişkin Cronbach Alpha katsayıları, Duygusal Bağlılık .67; Devam Bağlılığı .76; Normatif Bağlılık .74'tür (Yıldırım, 2002). Bu çalışma için ölçeğin Cronbach Alfa güvenilirlik katsayısı .85 bulunmuştur. Ölçeğin faktörleri için hesaplanan güvenirlik katsayıları sırasıyla duygusal bağlılık için .78, devamlılık bağlılığ için .64 ve normatif bağlllık için .74 olarak bulunmuştur.

\subsection{Verilerin Analizi ve Kullanılan İstatistiksel Yöntemler}

Veri analizi temel olarak iki aşamada gerçekleştirilmiştir. Birinci aşamada, bilgisayar ortamına aktarılan veriler eksik ya da hatalı değer, aykırı değer ve çoklu değişme açısından incelenmiş; ikinci aşamada ise araştırmanın alt problemleri çözümlenmiştir. Hatalı değer analizinde, yanlışlıkla hatalı girildiği düşünülen değerler düzeltilmiştir.

Araştırmada alt problemlerin çözümlenebilmesi için öncelikle her bir alt ölçekte yer alan maddelerin aritmetik ortalama değerleri belirlenerek o faktör için bir puan hesaplanmıştır. Analizler bu faktör puanları üzerinden yapılmıştır. Değişkenler arasındaki ilişkilerin hesaplanmasında Pearson Momentler Çarpım Korelasyon Katsayısı (r) kullanılmıştır. Bununla birlikte, bağımsız değişkenlerin bağımlı değişkenleri yordama düzeylerini belirlemek amacıyla Çoklu Doğrusal Regresyon Analizi yapılmıştır. Regresyon analizlerinin yorumlanmasında, standartlaştırılmış Beta $(\beta)$ katsayıları ve bunların anlamlılı̆̆ına ilişin t-testi sonuçları dikkate alınmıştır. Verilerin analizinde .05 anlamlılık düzeyi esas alınmıştır.

\section{Bulgular}

\section{Birinci Alt Probleme İlişkin Bulgular}

Araştırmaya katılan okul müdürlerinin genel öz yeterlik ve örgütsel bağlılık algılarına ilişkin bulgular Tablo 1'de yer almaktadır. 
Tablo 1. Genel Öz Yeterlik ve Örgütsel Bă̆lllık Boyutlarına İlişkin Aritmetik Ortalama ve Standart Sapma Değerleri

\begin{tabular}{lcl}
\hline Alt Boyutlar & $\bar{X}$ & Ss \\
\hline 1. Duygusal bağllık & 3.95 & .73 \\
\hline 2. Devam bağll1ı̆̆1 & 3.26 & .69 \\
\hline 3. Normatif bağllık & 3.50 & .77 \\
\hline 4. Çaba ve direnç & 3.33 & .43 \\
\hline 5. Yetenek ve güven & 3.42 & .41 \\
\hline 6.Örgütsel bağlllık (Toplam) & 3.41 & .58 \\
\hline 7. Genel öz yeterlik (Toplam) & 3.37 & .41 \\
\hline
\end{tabular}

Çalışma grubundaki okul müdürlerinin genel öz yeterlik ve örgütsel bağllılı algılarına ilişkin dağılımlar incelendiğinde; genel öz yeterlik puan ortalamasının, ( $\bar{X}: 3.37$ ) olduğu görülmektedir. Örgütsel bağlllık algilarına ilişkin dağılımlara bakıldığında ise, en yüksek ortalama duygusal bağlılık boyutunda ( $\bar{X}: 3.95)$ olurken, en düşük ortalamanın devam bağlllığ boyutunda ( $\bar{X}: 3.26$ ) olduğu görülmektedir.

Okul müdürlerinin genel öz yeterlik ve örgütsel bağlllıkları arasındaki ilişkiyi belirlemek için Pearson momentler çarpımı korelasyonu tekniği uygulanmış ve sonuçlar Tablo 2'te verilmiştir.

Korelasyon katsayısının 1.00 olması mükemmel pozitif bir ilişkiyi; 1.00 olması mükemmel negatif bir ilişkiyi; 0.00 olması ilişkinin olmadığını gösterir. Korelasyon katsayısının mutlak değer olarak 0.70-1.00 arasında olması yüksek, 0.70-0.30 arasında olması orta, 0.30-0.00 arasında olması ise düşük düzeyde bir ilişki olarak tanımlanabilir (Büyüköztürk, 2007).

\section{İkinci Alt Probleme İlişkin Bulgular}

Araştırmanın sonraki aşamasında okul müdürlerinin genel öz yeterlik algıları ile örgütsel bağlllık arasındaki korelasyonlar incelenerek sonuçlar Tablo 2' de sunulmuştur. 
Tablo 2. Okul Müdürlerinin Genel Öz Yeterlik ve Örgütsel Bağhllık Alglları Arasındaki İlişki

\begin{tabular}{|c|c|c|c|c|c|c|c|}
\hline Alt boyutlar & 1 & 2 & 3 & 4 & 5 & 6 & 7 \\
\hline 1. Duygusal bağlllık & - & & & & & & \\
\hline 2. Devam bağlılığ1 & $.41^{* *}$ & - & & & & & \\
\hline 3. Normatif bağlılık & $.48^{* *}$ & $.72^{* *}$ & - & & & & \\
\hline 4. Çaba ve direnç & $.23^{*}$ & $.26^{* *}$ & $.41^{* *}$ & - & & & \\
\hline 5. Yetenek ve güven & $.28^{* *}$ & $.33^{* *}$ & $.49^{* * *}$ & $.82^{* *}$ & - & & \\
\hline $\begin{array}{l}\text { 6.Örgütsel bağllilı } \\
\text { (Toplam) }\end{array}$ & $.76^{* *}$ & $.85^{* *}$ & $.89^{* *}$ & $.36^{* *}$ & $.44^{* *}$ & - & \\
\hline $\begin{array}{l}\text { 7. Genel öz yeterlik } \\
\text { (Toplam) }\end{array}$ & $.26^{* *}$ & $.30^{* *}$ & $.46^{* *}$ & $.87^{* *}$ & $.93^{* *}$ & $.41^{* *}$ & - \\
\hline
\end{tabular}

Tablo 2 incelendiğinde araştırmaya katılan okul müdürlerinin genel öz yeterlik ve örgütsel bağlılıkları arasında anlamlı ilişkilerin olduğu görülmektedir.

Araştırmaya katılan okul müdürlerinin genel öz yeterlik ve örgütsel bağlılık algılarına ilişkin toplam puanları arasında $(\mathrm{r}=.41, \mathrm{p}<.01)$ pozitif yönde, orta düzeyde anlamlı bir ilişki olduğu görülmektedir.

Örgütsel bağlılık ölçeğinin duygusal bağlllık boyutu ile genel öz yeterlilik ölçeğinin çaba ve direnç $(r=.23, p<.05)$ ile yetenek ve güven boyutları arasında pozitif yönde ve düşük düzeyde anlamlı ilişki bulunmuştur.

Bunun yanında, örgütsel bağlllığın devam bağlllığı boyutu ile genel öz yeterlik ölçeğinin çaba ve direnç $(r=.26, p<.01)$, ile yetenek ve güven $(\mathrm{r}=.33, \mathrm{p}<.01)$ boyutları arasında pozitif yönde anlamlı ilişki olduğu görülmektedir.

Son olarak örgütsel bağlllığın normatif bağlılık boyutu ile genel öz yeterlik ölçeğinin çaba ve direnç $(\mathrm{r}=.41, \mathrm{p}<.01)$, ile yetenek ve güven $(\mathrm{r}=.49$, $\mathrm{p}<.01)$ boyutları arasında pozitif yönde orta düzeyde anlamlı ilişki bulunmuştur. 


\section{Üçüncü Alt Probleme İlişkin Bulgular}

\section{Duygusal Bă̆lılı̆̆ın Yordanması}

Duygusal bağlılığın yordanmasına ilişkin çoklu doğrusal regresyon analizi sonuçları Tablo 3'te verilmiştir.

Tablo 3. Duygusal Bă̆lılığın Yordanmasına İlişkin Regresyon Analizi Sonuçları

\begin{tabular}{lccccc}
\hline Değişken & B & Sh & $\beta$ & $t$ & $p$ \\
\hline Sabit & 2,282 &, 599 & - & 3,813 &, 000 \\
\hline Çaba ve direnç &, 007 &, 284 &, 004 &, 026 &, 980 \\
\hline Yetenek ve güven &, 481 &, 294 &, 275 & 1,634 &, 105 \\
\hline $\mathrm{F}=4.109, \mathrm{p}<.01, \mathrm{R}=.278$, & $\mathrm{R}^{2}=.077$ & & & &
\end{tabular}

Tablo 3'te görüldüğü gibi, genel öz yeterlik ölçeğinin çaba ve direnç, yetenek ve güven boyutlarının birlikte, örgütsel bağlılığın duygusal bağlllık boyutunu yordama gücü istatistiksel olarak anlamlı bulunmuştur ( $\mathrm{F}=4.409$, p<.01). Genel öz yeterlik ölçeğinin tüm boyutları birlikte duygusal bağlılık puanındaki değişimin \%8'ini ( $\left.\mathrm{R}=.29, \mathrm{R}^{2}=.08\right)$ açıklayabilmektedir. Genel öz yeterlik ölçeğinin çaba ve direnç $(\beta=.004, p>.05)$ ile yetenek ve güven $(\beta=.275, \mathrm{p}>.05)$ boyutları duygusal bağlılığın tek başına anlamlı yordayıcısı olmadığı görülmektedir.

\section{Devam Bă̆lılı̆̆ının Yordanması}

Devam bağlılığının yordanmasına ilişkin çoklu doğrusal regresyon analizi sonuçları Tablo 4' de verilmiştir.

Tablo 4. Devam Bă̆lhlı̆̆ının Yordanmasına İlişkin Çoklu Regresyon Analizi Sonuçları

\begin{tabular}{lccccc}
\hline Değişken & B & Sh & $\boldsymbol{\beta}$ & $\boldsymbol{t}$ & $\boldsymbol{p}$ \\
\hline Sabit & 1,410 &, 553 & - & 2,551 &, 012 \\
\hline Çaba ve direnç &,- 031 &, 262 &,- 019 &,- 116 &, 908 \\
\hline Yetenek ve güven &, 569 &, 272 &, 346 & 2,096 &, $039^{*}$ \\
\hline $\mathrm{F}=6.016, \mathrm{p}<.01, \mathrm{R}=.331$, & $\mathrm{R}^{2}=.091$ & & & &
\end{tabular}

Tablo 4'te görüldüğü gibi, genel öz yeterlik ölçeğinin çaba ve direnç, yetenek ve güven boyutlarının birlikte, örgütsel bağllllğın devam bağlllığı boyutunu yordama gücü istatistiksel olarak anlamlı bulunmuştur ( $\mathrm{F}=6.016$, $\mathrm{p}<.01)$. Genel öz yeterlik ölçeğinin tüm boyutları birlikte devam bağlılığı puanındaki değişimin \%9'unu ( $\left.\mathrm{R}=.33, \mathrm{R}^{2}=.09\right)$ açıklayabilmektedir. Genel öz yeterlik ölçeğinin yetenek ve güven $(\beta=.272, p<.01)$ boyutu araştırmaya 
katılan okul müdürlerinin devam bağlılık algılarını pozitif yönde ve anlamlı düzeyde yordamaktadır. Genel öz yeterlik ölçeğinin çaba ve direnç ( $\beta=-.019$, p>.05 boyutu araştırmaya katılan okul müdürlerinin devam bağlllık algılarının tek başına anlamlı yordayıcısı olmadığı görülmektedir.

\section{Normatif Bă̆lılı̆̆ın Yordanması}

Normatif bağllı̆ı̆ın yordanmasına ilişkin çoklu doğrusal regresyon analizi sonuçları Tablo 5'de verilmiştir.

Tablo 5. Normatif Bağhllı̆̆ın Yordanmasına İlişkin Çoklu Regresyon Analizi Sonuçları

\begin{tabular}{lccccc}
\hline Değişken & B & Sh & $\boldsymbol{\beta}$ & $\boldsymbol{t}$ & $\boldsymbol{p}$ \\
\hline Sabit &, 413 &, 570 & - &, 725 &, 470 \\
\hline Çaba ve direnç &, 033 &, 271 &, 019 &, 123 &, 902 \\
\hline Yetenek ve güven &, 870 &, 280 &, 474 & 3,106 &, $002^{*}$ \\
\hline $\mathrm{F}=15.432, \mathrm{p}<.01, \mathrm{R}=.489$, & $\mathrm{R}^{2}=.240$ & & & &
\end{tabular}

Tablo 5'te görüldüğü gibi, genel öz yeterlik ölçeğinin çaba ve direnç, yetenek ve güven boyutlarının birlikte, örgütsel bağlllığın normatif bağlllık boyutunu yordama gücü istatistiksel olarak anlamlı bulunmuştur ( $\mathrm{F}=15.432$, $\mathrm{p}<.01)$. Genel öz yeterlik ölçeğinin tüm boyutları birlikte normatif bağlllık puanındaki değişimin \%24'ünü $\left(R=.49, R^{2}=.24\right)$ açılayabilmektedir. Genel öz yeterlik ölçeğinin yetenek ve güven $(\beta=.474, \mathrm{p}<.01)$ boyutu araştırmaya katılan okul müdürlerinin normatif bağlılık algılarını pozitif yönde ve anlamlı düzeyde yordamaktadır. Çaba ve direnç $(\beta=.019, p>.01)$ normatif bağlılığın tek başına anlamlı yordayıcısı değildir.

\section{Örgütsel Bağlılığın Yordanması}

Örgütsel bağlllığın yordanmasına ilişkin çoklu doğrusal regresyon analizi sonuçları Tablo 6' de verilmiştir.

Tablo 6. Örgütsel Bağhllı̆̆ın Yordanmasına İlişkin Çoklu Regresyon Analizi Sonuçları

\begin{tabular}{lccccc}
\hline Değişken & B & Sh & $\boldsymbol{\beta}$ & $\boldsymbol{t}$ & $\boldsymbol{p}$ \\
\hline Sabit & 1,369 &, 463 & - & 2,958 &, 004 \\
\hline Çaba ve direnç &, 003 &, 220 &, 002 &, 015 &, 988 \\
\hline Yetenek ve güven &, 640 &, 227 &, 442 & 2,815 &, $006^{*}$ \\
\hline
\end{tabular}

$\mathrm{F}=11.997, \mathrm{p}<.01, \mathrm{R}=.443, \mathrm{R}^{2}=.197$ 
Tablo 6'da görüldüğü gibi, genel öz yeterlik ölçeğinin çaba ve direnç, yetenek ve güven boyutlarının birlikte, örgütsel bağlılığı yordama gücü istatistiksel olarak anlamlı bulunmuştur (F=11.997, p<.01). Genel öz yeterlik ölçeğinin tüm boyutları birlikte örgütsel bağlılık puanındaki değişimin \%20'sini $\left(R=.44, R^{2}=.20\right)$ açıklayabilmektedir. Genel öz yeterlik ölçeğinin yetenek ve güven $(\beta=.442, \mathrm{p}<.01)$ boyutu araştırmaya katılan okul müdürlerinin örgütsel bağlllık algılarını pozitif yönde ve anlamlı düzeyde yordamaktadır. Çaba ve direnç $(\beta=.002, \mathrm{p}>$.01) örgütsel bağlllığın tek başına anlamlı yordayıcısı değildir.

\section{Tartışma Sonuç ve Öneriler}

$\mathrm{Bu}$ araştırmada, ilkokullarda görev yapan müdürlerin genel öz yeterlik ile örgütsel bağlılık algıları arasındaki ilişkiler incelenmiştir. Araştırma sonuçlarına göre, genel öz yeterlik ölçeğinin yetenek ve güven boyutu örgütsel bağlılığı anlamlı düzeyde yordamıştır.

Araştırmada, okul müdürlerinin genel öz yeterlik inançlarının yüksek düzeyde olduğu bulunmuştur. Genel öz yeterlik ölçeğinin boyutlarından, yetenek ve güven en yüksek düzeyde algılanan boyut olurken, en düşük düzeyde değerlendirilen boyutun çaba ve direnç olduğu saptanmıştır. Benzer şekilde ilköğretim okul müdürlerinin genel öz yeterlik inançlarının çeşitli değişkenler açısından inceleyen Okutan ve Kahveci, (2012) okul müdürlerinin genel öz yeterlik inançlarının yüksek olduğunu bulmuştur. Uysal ve Kösemen ise (2013) öğretmen adaylarının genel öz yeterlik inançlarının orta düzeyde bulmuştur. Öz yeterlikle ilgili çalışmalara bakıldığında Gençtürk ve Memiş (2010) ilköğretim okulu öğretmenlerinin genel öz yeterlik ve alt boyutlarında kendilerini oldukça yeterli algıladıklarını bulmuştur. Öz yeterlik ve tükenmişlik ilişkisini inceleyen Bolat (2011) çalışanların öz yeterlik algısını orta düzeyde bulmuştur. Müfettiş, okul müdürü ve öğretmen algılarına göre, ilköğretim okulu müdürlerinin yeterliklerini inceleyen Dönmez (2002) de genel olarak, okul müdürlerinin kendilerini müfettiş ve öğretmenlere göre daha yeterli algıladıklarını bulmuştur. Yapılan bu araştırmalardaki bulgular araştırma sonuçlarını desteklemektedir. Öz yeterlik düzeyi, harekete geçmek için güdüleri engelleyebilir ya da artırabilir. Öz yeterliği yüksek olan bireyler daha karmaşık ve riskli görevleri seçebilirler, hedefleri yüksektir ve bu hedeflere ulaşmak için azimle çalışırlar (Ünal-Keskin ve Orgun, 2006). Okul müdürlerinin genel öz yeterliklerinin yüksek çıkması olumlu bir durum olarak değerlendirilebilir. Bu durum, okul müdürlerinin okulda doğru kararlar alabilmelerine ve eylemlerde bulunabilmelerine, yüksek hedefler belirlemelerine ve ulaşmalarına yardımcı olacağı şeklinde yorumlanabilir. 
Araştırmada örgütsel bağlllık boyutlarından, duygusal bağllık en yüksek düzeyde algılanan boyut olurken, en düşük düzeyde değerlendirilen boyutun devam bağl1lı̆̆ı olduğu saptanmıștır. Araştırmaya katılan okul müdürlerinin örgütsel bağlılıkları yüksek düzeyde bulunmuştur. Benzer şekilde akademisyenlerin örgütsel bağlılık düzeylerini inceleyen Pelit, Boylu ve Güçer, (2007) akademisyenlerin gerek çalıştıkları fakülteye gerekse üniversitenin geneline yönelik söz konusu bu üç bağlllıkla ilgili görüşlerine göre, en yüksek düzeyde katılım gösterdikleri ifadeler duygusal bağlllıkla ilgili ifadeler olurken; onu sırasıyla normatif ve devam bağllığı ile ilgili ifadeler izlemiştir. Kurşunoğlu, Bakay ve Tanrıöğen (2010) ve Sezgin (2010) ilköğretim okulu öğretmenlerinin örgütsel bağlllık düzeylerini incelemiş elde edilen bulgulara göre öğretmenlerin duygusal bağlılıklarının en yüksek, devam bağlılıklarının da en düşük düzeyde olduğu bulunmuştur. Yapılan bu araştırmalardaki bulgular araştırma sonuçlarını desteklemektedir. Duygusal bağlılık, örgütsel bağlılığın unsurlarından biri olarak, örgüte duyulan bağlılığın en kuvvetli olduğu bağlllık türüdür. Duygusal bağlllık, örgüt amaç ve değerlerini benimseme, içinde bulunulan kurumda kariyerini sürdürmeye istekli olma ve örgüt için çaba sarf etmeye gönüllü olma anlamına gelmektedir (Çekmecelioğlu, 2006). Okul müdürlerinin duygusal bağlllığının yüksek bir ortalamaya sahip olması olumlu bir durum olarak değerlendirilebilir. Araştırmada okul müdürlerinin duygusal bağlllıklarının güçlü olması okul için her zaman gönüllü olarak çalıştıkları ve daha fazla çaba sarf ettikleri şeklinde yorumlanabilir. Aynı zamanda okul müdürlerinin örgütsel bağlılıklarının yüksek bir ortalamaya sahip olması okullarının amaçlarını belirleyip, bu amaçları gerçekleştirmek için öncülük ettiklerini ve okulla ilgili her türlü faaliyetlere kendilerini daha fazla adadıkları söylenebilir.

Genel öz yeterliğin boyutları ile örgütsel bağl1lı̆̆ın boyutları arasında pozitif yönde anlamlı bir ilişki olduğu bulgulanmıştır. Aydoğdu (2008) öğretmen algılarına göre ilköğretim okullarında çalışan okul müdürlerinin yeterlikleri ile örgütsel bağlllık düzeyleri arasındaki ilişkiyi incelediği araştırmada okul müdürlerinin yeterlikleri ile örgütsel bağlllık düzeyleri arasında yüksek düzeyde bir ilişki olduğunu bulmuştur. Al (2007) yükseköğretim kurumlarındaki yabancı diller birimleri yöneticilerinin yönetsel yeterlik düzeyleri ile bu birimlerde görev yapmakta olan İngilizce öğretim elemanlarının örgütsel bağlllık düzeylerini incelemiş ve İngilizce öğretim elemanlarının örgütsel bağl1lık düzeyleri ile yabancı diller birimleri yöneticilerinin yönetsel yeterlik düzeyleri arasında pozitif yönde anlamlı bir ilişki bulmuştur. Valentine, Godkin ve Lucero (2002) kurumsal etik değerler, Cullen ve diğerleri (2003) ve Schwepker (2001) etik iklim, Panaccio ve 
Vandenberghe (2009) algılanan örgütsel destek, Rose ve diğerleri (2009) örgütsel öğrenme, Feather ve Rauter (2004) örgütsel vatandaşlık davranışı ile örgütsel bağlllık arasında pozitif bir ilişki bulmuştur. Ayrıca Avolio vd. (2004), Jackson vd. (2013) ve Joo vd., (2012) dönüşümcü liderlik, Kul ve Güçlü (2010) liderlik stilleri, Meyer ve Smith (2000) insan kaynakları uygulamaları olan örgütsel destek ve adalet, Demirel (2008) örgütsel güvenin alt boyutları ile örgütsel bağlılığın alt boyutları arasında pozitif bir ilişki bulmuştur. Okul müdürlerinin genel öz yeterlik inançlarının artması okula olumlu duygular beslemelerini sağlayarak örgütsel bağlllıklarını arttırdığı söylenebilir.

Regresyon analizi sonuçlarına göre, genel öz yeterliğin yetenek ve güven boyutu örgütsel bağlllığı anlamlı düzeyde yordamaktadır. Ancak genel öz yeterliğin çaba ve direnç boyutu ise örgütsel bağlllı̆̆ın tek başına anlamlı yordayıcısı değildir. Korkmaz (2011) öğretmenlerin görev yaptıkları okullardaki örgüt sağlığı ve örgütsel iklim algılarının örgütsel bağlılıklarını yordadığını, Aghdasi vd. (2011) mesleki stersin örgütsel bağlılık üzerine negatif, iş tatminin de bağlılık üzerine pozitif etkisini, Clinebell ve diğerleri (2013) de liderlik stillerinin alt boyutlarının örgütsel bağlllı̆̆ın alt boyutlarını yordadığını bulgulamıştır. Örgütsel bağlılıkla ilgili diğer çalışmalara bakıldığında Ada, Alver ve Atlı (2008), Başyiğit (2006), Boyacı (2010), Ekinci (2006) işgörenlerin örgüt içindeki iletişimlerinin örgütsel bağlılı̆̆ı etkilediği sonucuna varmıştır. Öz yeterlik inançları bireysel davranışın mükemmel belirleyicisidir. Güçlü öz yeterlik duygusuna sahip okul müdürleri hedeflerini gerçekleştirmede israrc1, aynı zamanda bağlamsal koşulları yerine getirmek için stratejiler uygulamada daha esnek ve isteklidirler. Buna karşılık, düşük yeterlik duygusuna sahip okul müdürleri başarısız işleri değiştirmede, uygun stratejileri belirlemede ve çevreyi kontrol etmede daha az istekli ve yetersizdir (Tschannen-Moran ve Gareis, 2004). Bu bağlamda öz yeterlik algısı birey için güçlü bir silah olmaktadır. Okul müdürünün kendine güvenmesi okulun geliştirilmesi sürecinde atacağı her adımda değişimi sağlayacak olan yenilikleri yapmaktan korkmayacak ve daha fazla sorumluluk almaktan çekinmeyecektir.

Bireysel başarılar sadece kişinin nitelikleri ve becerilerini değil, aynı zamanda başarılı bir şekilde belirli bir eylemi gerçekleştirmek için sahip olduğu yeteneğine olan inancını da gerektirir (Nir ve Kranot, 2006). Eğitim örgütlerinin etkililiğini arttırmak için okul müdürlerinin yönetim konusunda bilgi ve becerilere sahip olması gerekmektedir. Ancak sadece bilgi ve becerilere sahip olmaları yetmez bu bilgi ve becerileri kullanabilecek güçlü bir inanca sahip olmaları da gerekir. Dolayısıyla okul müdürlerinin 
yeteneklerine inanması okul için gerçekleştirilen bütün etkinliklerde kendini gösterecek olan bir özelliktir. Araştırma sonuçlarına göre okul müdürlerinin genel öz yeterlik inançları arttıkça örgütsel bağlılık düzeyleri de artmaktadır. Araştırmaya katılan okul müdürlerinin genel öz yeterlik algılarının yüksek düzeyde olması örgütsel bağlılıklarını etkilediği ve okula güçlü bir bağlllık gösterdikleri şeklinde yorumlanabilir.

Araştırmanın önemli sonuçları şöyle özetlenebilir: 1) Okul müdürlerinin genel öz yeterlikleri yüksek düzeyde bulunmuştur. 2) Örgütsel bağlllık boyutlarından, duygusal bağlllık en yüksek düzeyde algılanan boyut olurken, en düşük düzeyde algılanan boyut ise devam bağlılığı boyutudur. 3) Okul müdürlerinin örgütsel bağlılıkları yüksek düzeyde bulunmuştur. 4) Okul müdürlerinin genel öz yeterlik ve örgütsel bağlılık algıları arasında pozitif yönde, anlamlı bir ilişki belirlenmiştir. 5) Araştırmada genel öz yeterliğin yalnızca yetenek ve güven boyutu, örgütsel bağlllığ1 pozitif yönde ve anlamlı düzeyde yordamıştır. Bununla birlikte, araştırma örneklemini ilkokullarda görevli okul müdürlerinin oluşturması, araştırmanın bir sınırlılığı olarak kabul edilmeli ve sonuçlar bu doğrultuda yorumlanmalıdır.

Eğitim kurumlarının rekabet gücünü artıran etmenlerden biri de nitelikli ve örgütüne bağlı çalışanlara sahip olmalarıdır. Çünkü okullarına yüksek düzeyde bağlılık hisseden yöneticiler, örgütsel amaçlara ulaşma ve sonuçta örgütsel etkinliğin sağlanmasında son derece önemli roller üstlenmektedirler. Araştırma sonuçlarına dayanarak, okul müdürlerinin genel öz yeterlik inançları örgütsel bağlılıklarını sağlayan bir unsur olduğu görülmektedir. Okul müdürlerinin genel öz yeterlik inançları arttıkça okula bağlllık düzeyleri artmaktadır. Bu nedenle okul müdürlerinin genel öz yeterliklerinin yükseltilmesi için genel öz yeterlik konusunda bilinçlendirilmeleri ve bilgilendirilmeleri örgütsel bağlllıklarının artırılması açısından önemlidir. Olumsuz koşullar müdürlerin genel öz yeterlik inançlarını kaybetmesine sebep olabilir. Bu nedenle olumsuz koşullar en aza indirilmeli ve olumsuz koşulların oluşmaması için önlemler alınması önerilebilir.

Araştırma sonuçlarının özellikle gözlem, görüşme ve mülakat gibi nitel araştırmalarla desteklenmesi önerilebilir. Bu araştırma ilişkisel tarama modelinde olduğu için yorumlarda neden-sonuç ilişkisinden ziyade, karşılıklı ilişkiler vurgulanmıştır. Bu bağlamda, okul müdürlerinin genel öz yeterlikleri ile örgütsel bağlılıkları arasında neden-sonuç ilişkilerinin ortaya konulabileceği araştırmalar yapılabilir. 


\section{Kaynakça}

AÇIKALIN, A. (1994). Çağdaş Örgütlerde İnsan Kaynaklarının PersonelYönetimi, Pegem Yayınları, Ankara.

ADA, N., ALVER, İ. ve ATLI, F. (2008). Örgütsel İletişimin Örgütsel Bağlllığa Etkisi: Manisa Organize Sanayi Bölgesinde Yer Alan Ve İmalat Sektörü Çalışanları Üzerinde Yapılan Bir Araştırma. Ege Akademik Bakış, 8(2), 487-518.

AGHDASI, S., KIAMANESH, A. R. ve EBRAHIM, A. N. (2011). Emotional Intelligence and Organizational Commitment: Testing the Mediatory Role of Occupational Stress and Job Satisfaction. Procedia - Social and Behavioral Sciences 29,1965 - 1976.

AĞAOĞLU, E., ALTINKURT, Y., YILMAZ, K. ve KARAKÖSE, T. (2012). Okul Yöneticilerinin Yeterliklerine İlişkin Okul Yöneticilerinin ve Öğretmenlerin Görüşleri (Kütahya ili). Eğitim ve Bilim, 37( 164), 159174.

AK, M. (2006). Illköğretim Okulu Yöneticilerinin Değişimi Yönetme Yeterlikleri (Uşak ili örneği) (Yayımlanmamış Yüksek Lisans Tezi). Afyon Kocatepe Üniversitesi Sosyal Bilimler Enstitüsü.

AKIN, U. (2014). Okul Müdürlerinin İnisiyatif Alma Düzeyleri ile ÖzYeterlikleri Arasındaki İlişki [doi: 10.14527/kuey. 2014.006]. Kuram ve Uygulamada Eğitim Yönetimi Dergisi, 20(2), 125-149.

AKKOYUNLU, B., ORHAN, F., ve UMAY, A. (2005). Bilgisayar Öğretmenleri İçin "Bilgisayar Öğretmenliği Öz-Yeterlik Ölçeği" Geliştirme Çalışması. Hacettepe Üniversitesi Ĕ̆itim Fakültesi Dergisi, $29,1-8$.

AL, A. (2007). Üniversitelerdeki Yabancı Diller Birimleri Yöneticilerinin Yönetsel Yeterlik Düzeyi İle İngilizce Öğretim Elemanlarmnn Örgütsel Bă̆lllık Düzeylerinin Araştırılması (Yayımlanmamış Yüksek Lisans Tezi). Kocaeli Üniversitesi Sosyal Bilimler Enstitüsü.

ALLEN, N. J. ve MEYER, J. P. (1990). The Measurement and Antecedents of Affective, Continuance and Normative Commitment to the Organization. Journal of Occupational Psychology. 63, 1-18.

ARSLAN H. ve BEYTEKINN, F. (2004) İlköğretim Okul Müdürleri İçin Okul Liderliği Standartlarının Araştırılması. XIII. Ulusal Eğitim Bilimleri Kurultayı. Malatya: İnönü Üniversitesi, Eğitim Fakültesi, CD Formati.

AVOLIO, B. J., ZHU, W., KOH, W. ve BHATIA, P. (2004). Transformational Leadership Andorganizational Commitment: Mediating Role of Psychological Empowerment Andmoderating Role of Structural Distance. Journal of Organizational Behavior, 25(8), 951-68. 
AYDIN, M. (2010). Eğitim Yönetimi (9. Baskı). Ankara: Hatiboğlu.

AYDOĞDU, A. (2008). İlköğretim Okulu Öğretmenlerinin Algıladıkları Okul Müdürü Yeterlilikleri ile Örgütsel Bağhllık Düzeyleri Arasındaki İlişki (Yayımlanmamış Yüksek Lisans Tezi). Yeditepe Üniversitesi Sosyal Bilimler Enstitüsü.

AYPAY, A. (2010). Genel Öz Yeterlik Ölçeği'nin (GÖYÖ) Türkçe'ye Uyarlama Çalışması. İnönü Üniversitesi Eğitim Fakültesi Dergisi, 11(2), 113-131.

AZAR, A. (2010). Ortaöğretim Fen Bilimleri ve Matematik Öğretmeni Adaylarının Öz Yeterlik İnançları. ZKÜ Sosyal Bilimler Dergisi, 6(12), 235-252.

BABAOĞLAN, E. ve LİTCHKA, P. R. (2010). An Examination of Leadership Competencies of School Principals in Turkey and the United States. Education and Science, 35 (158), 58-74.

BANDURA, A. (1993). Perceived Self-Efficacy in Cognitive Development and Functioning, Educational Psychologist, 28(2), 117-148, DOI: 10.1207/s15326985ep2802_3. 28 Ağustos 2013 tarihinde erişilmiştir.

BANDURA, A. (1994). Self Efficacy. http://www.uky.edu/ eushe2/Bandura/ BanEncy.html. 26/9/2013 tarihinde erişilmiştir.

BANOĞLU, K. (2011). Okul Müdürlerinin Teknoloji Liderliği Yeterlikleri ve Teknoloji Koordinatörlüğü. Kuram ve Uygulamada Eğitim Bilimleri, 11(1), 199-213.

BAŞAR, H. (2000). Eğitim Denetçisi, Pegem A Yayıcılık, Ankara.

BAŞYİĞİT, A. (2006). Örgütsel İletişimin Örgütsel Bağlllık Üzerine Etkisi (Yayınlanmamış Yüksek lisans tezi). Dumlupınar Üniversitesi Sosyal Bilimler Enstitüsü.

BENIGHT, C. C. ve BANDURA, A. (2004). Social Cognitive Theory of Posttraumatic Recovery: The Role of Perceived Self-Efficacy. Behaviour Research and Therapy 42, 1129-1148.

BLACK, L. T. (2003). The Development and the Validation of the Principal Efficacy Scale (Unpublished doctoral dissertation). Sam Houston State University, USA.

BOLAT, O. İ. (2011). Öz Yeterlik ve Tükenmişlik İlişkisi: Lider-Üye Etkileşiminin Aracılık Etkisi. Ege Akademik Bakış,11(2), 255 - 266.

BOYACI, M. F. (2010 ). Örgütsel Bağgllı̆̆ın Arttırılmasında Etkin İletişim - Bir Uygulama (Yayımlanmamış Yüksek Lisans Tezi). Gazi Üniversitesi Eğitim Bilimleri Enstitüsü.

BULUÇ, B. (2009). Sınıf Öğretmenlerinin Algılarına Göre Okul Müdürlerinin Liderlik Stilleri ile Örgütsel Bağlılık Arasındaki İlişki. Kuram ve Uygulamada Ĕ̆itim Yönetimi, 15(57), 5-34. 
BURSALIOĞLU, Z. (2012). Okul Yönetiminde Yeni Yapı ve Davranış (17. Basım). Ankara: Pegem Akademi.

BÜLBÜL, T. ve ÇUHADAR, Ç. (2012). Okul Yöneticilerinin Teknoloji Liderliği Öz-Yeterlik Algıları İle Bilgi ve İletişim Teknolojilerine Yönelik Kabulleri Arasındaki İlişkinin İncelenmesi. Mehmet Akif Ersoy Üniversitesi Ĕ̆itim Fakültesi Dergisi, Sayı 23, 474 - 499.

BÜYÜKÖZTÜRK, Ş., ÇAKMAK, E. K., AKGÜN, Ö. E., KARADENIZ, Ş., DEMIREL, F. (2012) Bilimsel Araştırma Yöntemleri, Geliştirilmiş 11. Bask1, s 249., Pegem Akademi, Ankara.

CAN, T.(2003). Bolu Orta Öğretim Okulları Yöneticilerinin Teknolojik Liderlik Yeterlilikleri. The Turkish Online Journal of Educational Technology, 2(3), Article 12.

CARRIERE, J. ve BOURQUE, C. (2009). The Effects of Organizational Communication on Job Satisfaction and Organizational Commitment in a Land Ambulance Service and the Mediating Role of Communication Satisfaction. Career Development International, 14(1), 29-49.

CULLEN, J. B., PARBOTEEAH, K. P. ve VICTOR B. (2003). The Effects of Ethical Climates on Organizational Commitment: A Two-Study Analysis. Journal of Business Ethics, 46, 127-141.

CLINEBELL, S., SKUDIENĖ, V., TRIJONYTE, R. ve REARDON, J. (2013). Impact Of Leadership Styles On Employee Organizational Commitment. The Clute Institute International Academic Conference Paris, France 2013 http://www.cluteinstitute.com/index.html

ÇALIK, C. ve ŞEHITOĞLU, E. T. (2006). Okul Müdürlerinin İnsan Kaynakları Yönetmi İşlevlerini Yerine Getirebilme Yeterlikleri. Milli Eğitim Dergisi, 35 (170).

ÇEKMECELİOĞLU, H. G. (2006). Örgüt İklimi, Duygusal Bağlllık ve Yaratıcılık Arasındaki İlişkilerin Değerlendirilmesi: Bir Araştırma. İktisadi ve İdari Bilimler Dergisi, 20(2), 295-310.

ÇETIN, M. ve ADIGÜZEL, S. (2006). İstanbul İli Resmî İlköğretim Okulu Müdürlerinin Uzmanllk Yeterliklerinin İncelenmesi. Mersin Üniversitesi Ĕ̆itim Fakültesi Dergisi, 2(2), 167-183.

ÇETiN, F., BASIM, H. N. ve AYDOĞAN, O. (2011). Örgütsel Bağlllığın Tükenmişlik ile İlişkisi: Öğretmenler Üzerine Bir Araştırma. Selçuk Üniversitesi Sosyal Bilimler Enstitüsü Dergisi, 25, 61-70.

ÇINAR, İ. (2004). Bilgi Yönetiminde Eğitim Yöneticilerinin Yeterlikleri: Malatya Örneği. XIII. Ulusal Eğitim Bilimleri Kurultayı, 6-9 Temmuz 2004 İnönü Üniversitesi, Eğitim Fakültesi, Malatya. 
DEMİREL, Y. (2008). Örgütsel Güvenin Örgütsel Bağlllık Üzerine Etkisi: Tekstil Sektörü Çalışanlarına Yönelik Bir Araştırma. Yönetim ve Ekonomi, 15(2), 179-194.

DÖNMEZ, B. (2002). Müfettiş, Okul Müdürü ve Öğretmen Algılarına Göre İlköğretim Okulu Müdürlerinin Yeterlikleri. Kuram ve Uygulamada Eğitim Yönetimi Dergisi, Sayı: 29, 27-45.

ERBAŞ, G. (2008). Yönetici ve İsgören Arasındaki İletişimin Kalitesi ile Örgütsel Bă̆lllık İlişkisi Üzerine Bir Araştırma (Yayımlanmamış Yüksek lisans tezi). Marmara Üniversitesi Eğitim Bilimler Enstitüsü.

ERDEM, R. (2007). Örgüt Kültürü Tipleri ile Örgütsel Bağlllık Arasındaki İlişki: Elâzı̆̆ İl Merkezindeki Hastaneler Üzerinde Bir Çalışma. Eskişehir Osmangazi Üniversitesi İ̈BF Dergisi, 2(2), 63-79.

EKİNCI, K. (2006). Örgütsel İletişim ve Örgütsel Bă̆lllık Arasındaki İlişki (Yayımlanmamış Yüksek Lisans Tezi). Atatürk Üniversitesi Sosyal Bilimler Enstitüsü.

ELMA, C. (1998). İlköğretim Okulları Yöneticilerinin Çatışmayı Yönetme Yeterlikleri (Yayımlanmamış Yüksek lisans tezi). Ankara Üniversitesi Sosyal Bilimler Enstitüsü.

FAN, W. ve WILLIAMS, C. M. (2010). The Effects of Parental İnvolvement on Students' Academic Self-Efficacy, Engagement and İntrinsic Motivation. Educational Psychology, 30(1), 53-74.

FEATHER, N. T. ve RAUTER, K. A. (2004). Organizational Citizenship Behaviours in Relation to Job Status, Job İnsecurity, Organizational Commitment and Identification, Job Satisfaction and Work Values. Journal of Occupational and Organizational Psychology 77, 81-94.

GENÇTÜRK, A. ve MEMIŞ, A. (2010). İlköğretim Okulu Öğretmenlerinin Öz-Yeterlik Algıları ve İş Doyumlarının Demografik Faktörler Açısından İncelenmesi. İlköğretim Online, 9(3), 1037-1054.

GÖKÇE, F. (2008). Değişimin Kavramsal Modelleri ve Değişim Sürecinde Eğitim Yöneticilerinin Yeterlikleri. Milli Ĕ̆itim, 172, 237-252.

GÜNEY, S. (2011). Örgütsel Davranış. İstanbul: Nobel yayın dağıtım.

GÜRBÜZ, S.( 2006). Örgütsel Vatandaşlık Davranışı ile Duygusal Baglılık Arasındaki İlişkilerin Belirlenmesine Yönelik Bir Araştırma. Ekonomik ve Sosyal Araştırmalar Dergisi, 3,48-75.

HEMEDOĞLU, E. ve EVLIYYAOĞLU, F. (2012). Çalışanların Dönüşümcü Liderlik Algılarının Örgütsel Bağlılıkları Üzerindeki Etkilerinin İncelenmesi. İşletme Araştırmaları Dergisi, 4(1), 58-77.

HSIEH, P., SULLIVAN, J. R. ve GUERRA, N. S. (2007). A Closer Look at College Students: Self-Efficacy and Goal Orientation. Journal of Advanced Academics, 18(3), 454-476. 
HULPIA, H., DEVOS, G. ve KEER, H. V. (2011). The Relation between School Leadership from a Distributed Perspective and Teachers' Organizational Commitment: Examining the Source of the Leadership Function. Educational Administration Quarterly 47(5) 728771.

JACKSON, T. A., MEYER, J. P. ve WANG, X.-H. (2013). Leadership, Commitment, and Culture: A Meta-Analysis. Journal of Leadership $\mathcal{E}$ Organizational Studies 20(1) 84- 106.

JOO, B.-K., YOON, H. J. ve JEUNG, C.-W. (2010). The Effects of Core SelfEvaluations and Transformational Leadership on Organizational Commitment. Leadership \& Organization Development Journal, 33( 6), 564-582.

KAHYAOĞLU, M. ve YANGIN, S. (2007). İlköğretim Öğretmen Adaylarının Mesleki Özyeterliklerine İlişkin Görüşleri. Kastamonu Ĕ̆itim Dergisi,15(1), 73-84.

KARAKUŞ, M. ve TÖREMEN, F. (2006). Denetçi Gözüyle Yönetici Yeterlikleri: İlköğretim Okulu Yöneticileri Üzerine Bir Araştırma. Kazım Karabekir Eğitim Fakültesi Dergisi, Sayı:13, 175-189.

KARASAR, N. (2006). Bilimsel Araştırma Yöntemi, Ankara: Nobel Yayınları.

KARCIOĞLU, F. ve ÇELIKK, E. (2012). Örgütsel İletişimin Etkinliği Açısından Kurumsal Bloglar ve Birkaç Kurumsal Blogun İncelenmesi. Atatürk Üniversitesi İktisadi ve İdari Bilimler Dergisi, 23(3),

KAYA, H. (2008). Kamu ve Özel Sektör Kuruluşlarının Örgütsel Kültürünün Analizi ve Kurum Kültürünün Çalışanların Örgütsel Bağlıllığına Etkisi: Görgül Bir Araştırma. Maliye Dergisi, Sayı 155, 119-143.

KOMBIÇAK, M. (2008). İlköğretim Okul Müdürlerinin Yeterliliklerinin İncelenmesi (Yayımlanmamış Yüksek Lisans Tezi). Yeditepe Üniversitesi Sosyal Bilimler Enstitüsü.

KORKMAZ, M. (2011). İlköğretim Okullarında Örgütsel İklim ve Örgüt Sağllı̆ının Örgütsel Bağlılık Üzerindeki Etkisi. Kuram ve Uygulamada Eğitim Yönetimi, 17(1), 117-139.

KUL, M. ve GÜÇLÜ, M. (2010). Okul Yöneticilerinin Liderlik Stilleri ile Beden Eğitimi Öğretmenlerinin Örgütsel Bağll1kkları Arasındaki İlişki. Uluslararası İnsan Bilimleri Dergisi, 7(2), 1021-1038.

KURŞUNOĞLU, A., BAKAY, E. ve TANRIÖĞEN, A. (2010). İlköğretim Okulu Öğretmenlerinin Örgütsel Bağlılık Düzeyleri. Pamukkale Üniversitesi Ĕ̆itim Fakültes Dergisi, Sayı 28, 101-11.

LEITHWOOD, K. ve JANTZI, D. (2008). Linking Leadership to Student Learning: The Contributions of Leader Efficacy. Educational Administration Quarterly, 44(4), 96-528. 
LUSZCZYNSKA,A., SCHOLZ,U ve SCHWARZER, R. (2005). The General Self-Efficacy Scale: Multicultural Validation Studies. The Journal of Psychology, 139(5), 439-457.

MARGOLIS, H. ve MCABE, P. P. (2003). Self-Efficacy: a Key to Improving the Motivation of Struggling Learners. Alternative Education for Children and Youth, 47(4), 162-169.

MARGOLIS, H. ve MCABE, P. P. 2006). Improving Self-Efficacy and Motivation: What to do, What to Say. Intervention in School and Clinic, 41(4), 218-227.

MEYER, J. P. ve SMITH, C. A. (2000). HRM Practices and Organizational Commitment: Test of a Mediation Model. Canadian Journal of Administrative Sciences, 17(4), 3 19-331.

MEMIŞOĞLU, S. P. ve ÖZSARIKAMIŞ, S. (2009). İlköğretim Okulu Yöneticilerinin Bilgi Yönetimi Yeterlikleri. Abant İzzet Baysal Üniversitesi Dergisi, 9(2) , 133-151.

MENTEŞE, S., ÜSTÜN, A. ve GÖKDELEN, A. (2012). İlköğretim Okulu Yöneticilerinin Okulun Parasal Kaynaklarını Yönetme Yeterlilikleri (Ordu İli Örneği). Hitit Üniversitesi Sosyal Bilimler Enstitüsü Dergisi, Sayı 2, 41-65.

MCCOLLUM, D. L., KAJS, L. T. ve MINTER, N. (2005). School Administrators' Efficacy: A Model and Measure. Allied Academies International Conference, Proceedings of the Academy of Educational Leadership, 10( 1), 29-32.

NIR, A. E. ve KRANOT, N. (2006). School principal's leadership style and teachers' self-efficacy. Planning and Changing, 37(3\&4), 205-218.

OKUTAN, M. ve KAHVECI, A. (2012). İlköğretim okul müdürlerinin genel öz yeterlik inançlarının çeşitli değişkenler açısından incelenmesi (Rize örneği). Kastamonu Eğitim Dergisi, 20(1), 27-42.

PAJARES, F. (2002). Gender and perceived self-efficacy in self- regulated learning. Theory Into Practice, 41(2), 116-125.

PANACCIO, A. ve VANDENBERGHE, C. (2009), Perceived organizational support, organizational commitment and psychological well-being: A longitudinal study. Journal of Vocational Behavior, 75, 224-236.

PEKER, S. ve SELÇUK, G. (2011). Okul müdürlerinin yeterliklerinin eğitim öğretim sürecine etkisi. CBÜ Sosyal Bilimler Dergisi, 9(2), 472-480.

PELITT, E., BOYLU, Y. ve GÜÇER, E. (2007). Gazi üniversitesi ticaret ve turizm eğitim fakültesi akademisyenlerinin örgütsel bağlllık düzeyleri üzerine bir araştırma. Ticaret ve Turizm Eğitim Fakültesi Dergisi, Say1: 1, 86- 114. 
ROSE, R. C., KUMAR, N. ve PAK, O. G. (2009), The effect of organizational learning on organizational commitment, job satisfaction and work performance. The Journal of Applied Business Research, 25(6), 55-66.

SEZGINN, F. (2010). Öğretmenlerin örgütsel bağlılığının bir yordayıcısı olarak okul kültürü. Eğitim ve Bilim, 35(156),142-159.

SCHWARZER, R.; BABLER, J.; KWIATEK, P. ve SCHRODER, K. (1997). The assessment of optimistic self-beliefs: comparison of the german, spanish, and chinese versions of the general self-efficacy scale. Applied Psychology: An International Review, 46 ( I ) , 69-88.

SCHWEPKER, C. H. (2001), Ethical climate's relationship to job satisfaction, organizational commitment, and turnover intention in the salesforce. Journal of Business Research, 54, 39- 52.

SILVERTHORNE, C. (2004). The impact of organizational culture and person-organization fit on organizational commitment and job satisfaction in Taiwan. The Leadership \& Organization Development Journal. 25( 7), 592-599.

SOMECH, A. ve DRACH-ZAHAVY, A. (2000). Understanding extra-role behavior in schools: The relationship between job satisfaction, sense of efficacy and teachers' extra-role behaviors. Teaching and Teacher Education, 16, 649-659.

SOMUNCU, F. (2008). Örgütsel bağlllık ve örgütsel bağhllığı geliştirme araçları: özel bir hizmet işletmesinde araştırma (Yayımlanmamış Yüksek Lisans Tezi). Anadolu Üniversitesi Sosyal Bilimler Enstitüsü.

SCHUNK, D. H. (1991). Self-efficacy and academic motivation. Educational Psychologist, 26, 207-231.

ŞAHIN, A. E. (2000). İlköğretim okulu müdürlerinin yeterlikleri. Kuram ve Uygulamada Ĕ̆itim Yönetimi, Sayı 22, 243-260.

Şİ̧̧MAN, M. (2012). Öğretim liderliği (4, baskı) Ankara: Pegem Akademi.

SÖNMEZ, V. ve ALACAPINAR, F. G. (2011). Örneklendirilmiş bilimsel araştırma yöntemleri. Ankara: Anı Yayıncılık.

TOLENTINO, R. C. (2013). Organizational commitment and job performance of the academic and administrative personnel. International Journal of Information Technology and Business Management.15(1), 51-59.

TOPLUER, A. (2008). İlköğretim okulu yöneticilerinin iletişim yeterlikleri ile örgütsel çatışma düzeyi arasındaki ilişki "Malatya ili örneği. (Yayımlanmamış Yüksek Lisans Tezi)., İnönü Üniversitesi, Malatya.

TULUNAY, Ö. (2010). Sinıf Öğretmenlerinin Tükenmişlik Düzeylerine Örgütsel Bağhllık ve Örgütsel İletişim İle İlişkisi (Sivas İli Örneği). Kırıkkale: 
Kırıkkale Üniversitesi Sosyal Bilimler Enstitüsü Yayınlanmammış Yüksek Lisans Tezi.

TSCHANNEN-MORAN, M. ve GAREIS, C. R. (2004). Principals' sense of efficacy Assessing a promising construct. Journal of Educational Administration, 42(5), 573-585.

TSCHANNEN-MORAN, M. ve GAREIS, C. R. (2005). Cultivating principals'sense of efficacy: Supports that matter. Presented at the annual meeting of the University Council for Educational Administration, Nashville, TN.

TÜRKMEN, H. (2008). İlköğretim okul müdürlerinin insan kaynakların yönetme yeterlilikleri (Yayımlanmamış Yüksek Lisans Tezi). Yeditepe Üniversitesi Sosyal Bilimler Enstitüsü.

UYSAL, İ. ve KÖSEMEN, S. (2013). Öğretmen adaylarının genel öz-yeterlik inançlarının incelenmesi. Journal of Research in Education and Teaching, 2, 217-226.

ÜNAL- KESKINN, G. ve ORGUN, F. (2006). Öğrencilerin öz etkililik-yeterlilik düzeyleri ile başa çıkma stratejilerinin incelenmesi. Anatolian Journal of Psychiatry, 7, 92-99.

ÜSTÜNER, M., DEMIRTAS, H.; CÖMERT, M. ve ÖZER, N. (2009). Ortaöğretim öğretmenlerinin öz-yeterlik algıları. Mehmet Akif Ersoy Üniversitesi Ĕ̆itim Fakültesi Dergisi, Sayı 17, 1-16.

VALENTINE, S., GODKİN, L. ve LUCERO, M. (2002). Ethical Context, Organizational Commitment, and Person-Organization Fit. Journal of Business Ethics 41: 349-360.

VUONG, M., BROWN-WELTY, S. ve TRACZ, S. (2010). The Effects of SelfEfficacy on Academic Success of First-Generation College Sophomore Students. Journal of College Student Development, 51( 1), 50-64.

YAVUZ, E. ve TOKMAK, C. İşgörenlerin Etkileşimci Liderlik ve Örgütsel Bağlılık ile İletişim Tutumlarına Yönelik Bir Araştırma. International Journal of Economic and Administrative Studies, 1(2), 17-34.

YILDIRIM, F ve İLHAN, İ. Ö. (2010). Genel Öz Yeterlik Ölçeği Türkçe Formunun Geçerlilik ve Güvenilirlik Çalışması. Türk Psikiyatri Derneği, 21(4), 301-8.

YILDIRIM, F. (2002). Çalışma Yaşamında Örgüte Bağlllık ve Örgütsel Adalet İlişkisi (Yayımlanmamış Yüksek Lisans Tezi)., Ankara Üniversitesi Sosyal Bilimler Enstitüsü.

YILMAZ, S. Ç. (2008). İlköğretim Okulu Yöneticilerinin Bilgisayar Teknolojisini Kullanma Yeterliklerinin Değerlendirilmesi (Yayımlanmamış Yüksek Lisans Tezi). Gazi Üniversitesi Eğitim Bilimleri Enstitüsü. 
A. AYIK, M. SAVAŞ, E. YÜCEL $\mid 218$

YOST, R. (2010). “I Think I Can": Mentoring as a Means of Enhancing Teacher Efficacy. The Clearing House: A Journal of Educational Strategies, Issues and Ideas, 75(4), 195-197.

ZIMMERMAN, B. J. (2000). Self-Efficacy: An Essential Motive to Learn. Contemporary Educational Psychology, 25(1), 82-91. 